University of Nebraska - Lincoln

DigitalCommons@University of Nebraska - Lincoln

2010

\title{
Resource Selection by Elk in an Agro-Forested Landscape of Northwestern Nebraska
}

\author{
David M. Baasch \\ University of Nebraska - Lincoln, baaschd2@gmail.com \\ Justin W. Fischer \\ USDA/APHIS/WS/National Wildlife Research Center, Justin.w.fischer@aphis.usda.gov \\ Scott E. Hygnstrom \\ University of Nebraska-Lincoln, shygnstrom1@unl.edu \\ Kurt C. Vercauteren \\ USDA National Wildlife Research Center, Fort Collins, CO, kurt.c.vercauteren@usda.gov \\ Andrew J. Tyre \\ University of Nebraska at Lincoln, atyre2@unl.edu
}

See next page for additional authors

Follow this and additional works at: https://digitalcommons.unl.edu/natrespapers

Part of the Natural Resources and Conservation Commons

Baasch, David M.; Fischer, Justin W.; Hygnstrom, Scott E.; Vercauteren, Kurt C.; Tyre, Andrew J.; Millspaugh, Joshua J.; Merchant, James W.; and Volesky, Jerry D., "Resource Selection by Elk in an AgroForested Landscape of Northwestern Nebraska" (2010). Papers in Natural Resources. 221.

https://digitalcommons.unl.edu/natrespapers/221

This Article is brought to you for free and open access by the Natural Resources, School of at DigitalCommons@University of Nebraska - Lincoln. It has been accepted for inclusion in Papers in Natural Resources by an authorized administrator of DigitalCommons@University of Nebraska - Lincoln. 


\section{Authors}

David M. Baasch, Justin W. Fischer, Scott E. Hygnstrom, Kurt C. Vercauteren, Andrew J. Tyre, Joshua J. Millspaugh, James W. Merchant, and Jerry D. Volesky 


\title{
Resource Selection by Elk in an Agro-Forested Landscape of Northwestern Nebraska
}

\author{
David M. Baasch - Justin W. Fischer • Scott E. Hygnstrom • \\ Kurt C. VerCauteren · Andrew J. Tyre $\cdot$ Joshua J. Millspaugh • \\ James W. Merchant $\cdot$ Jerry D. Volesky
}

Received: 13 April 2009/Accepted: 26 August 2010/Published online: 25 September 2010

(C) Springer Science+Business Media, LLC 2010

\begin{abstract}
In recent years, elk have begun recolonizing areas east of the Rocky Mountains that are largely agroforested ecosystems composed of privately owned land where management of elk is an increasing concern due to crop and forage depredation and interspecific disease transmission. We used a Geographic Information System, elk use locations $(n=5013)$, random locations $(n=$ $25,065)$, discrete-choice models, and information-theoretic methods to test hypotheses about elk resource selection in an agro-forested landscape located in the Pine Ridge region of northwestern Nebraska, USA. Our objectives were to determine landscape characteristics selected by female elk and identify publicly owned land within the Pine Ridge for potential redistribution of elk. We found distance to edge of cover influenced selection of resources by female elk most and that in areas with light hunting pressure, such as ours, this selection was not driven by an avoidance of roads.
\end{abstract}

D. M. Baasch $(\bowtie)$

School of Natural Resources, University of Nebraska,

135 Hardin Hall, 3310 Holdrege Street, Lincoln,

NE 68583-0982, USA

e-mail: baaschd@headwaterscorp.com

J. W. Fischer - K. C. VerCauteren

USDA/APHIS/WS/National Wildlife Research Center,

4101 Laporte Avenue, Fort Collins, CO 80521, USA

S. E. Hygnstrom

School of Natural Resources, University

of Nebraska, 415 Hardin Hall, 3310 Holdrege Street,

Lincoln, NE 68583-0982, USA

A. J. Tyre

School of Natural Resources, University of Nebraska,

414 Hardin Hall, 3310 Holdrege Street,

Lincoln, NE 68583-0982, USA
Female elk selected resources positioned near ponderosa pine cover types during all seasons, exhibited a slight avoidance of roads during spring and fall, selected areas with increased slope during winter and spring, and selected north- and east-facing aspects over flat areas and areas with south-facing slopes during winter months. We used our models to identified a potential elk redistribution area that had a higher proportion of landcover with characteristics selected by elk in our study area than the current herd areas and more landcover that was publicly owned. With appropriate management plans, we believe elk within the Potential Elk Redistribution Area would predominantly occupy publicly owned land, which would help minimize crop and forage damage on privately owned lands.

Keywords Agro-forested landscape - Cervus elaphus . Discrete choice $\cdot$ Elk $\cdot$ Nebraska $\cdot$ Resource selection

\section{J. J. Millspaugh \\ Department of Fisheries and Wildlife Sciences, \\ University of Missouri, 302 Natural Resources Building, \\ Columbia, MO 65211, USA}

\section{J. W. Merchant}

School of Natural Resources, University of Nebraska,

306 Hardin Hall, 3310 Holdrege Street, Lincoln,

NE 68583-0982, USA

J. D. Volesky

West Central Research and Extension Center,

University of Nebraska, 402 West State Farm Road,

North Platte, NE 69101, USA 


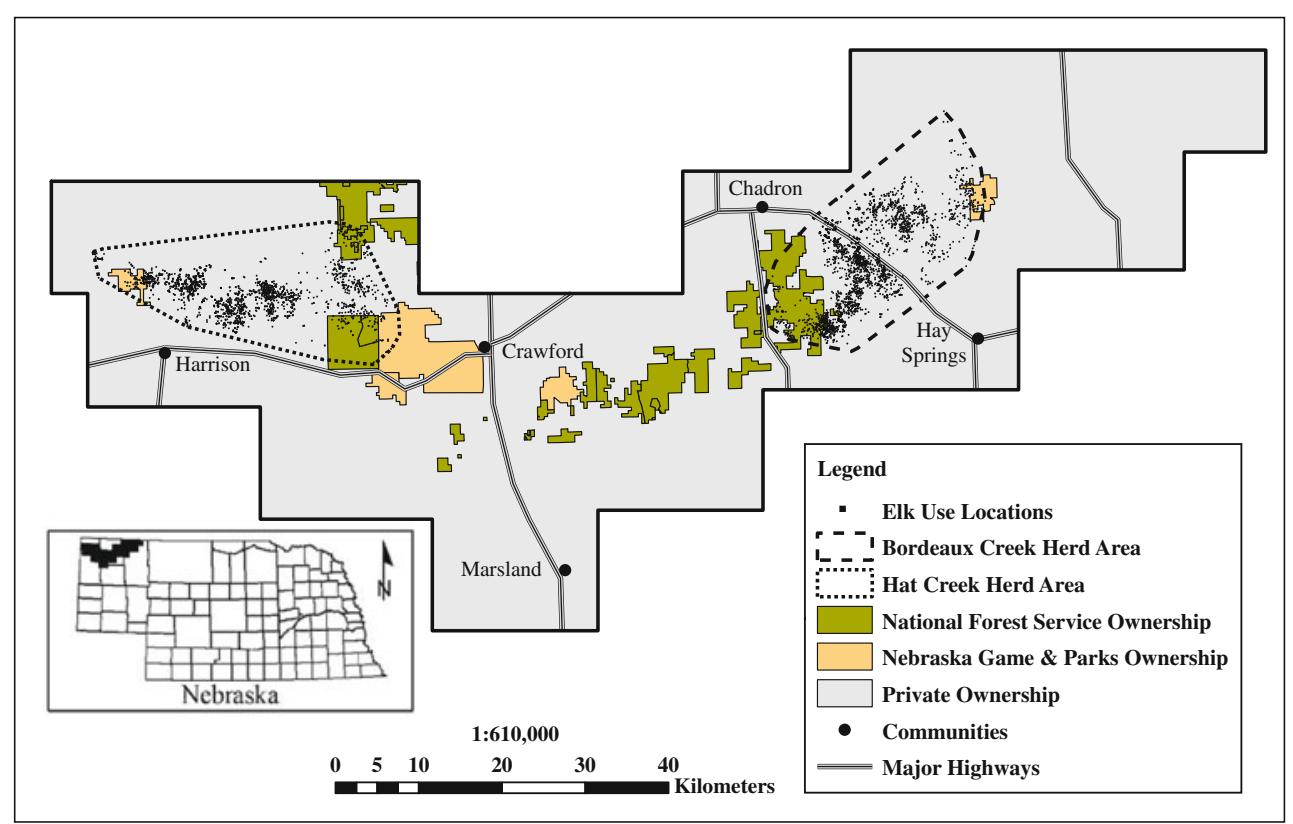

Fig. 1 Pine Ridge study area in northwestern Nebraska, USA with land ownership classification

\section{Introduction}

Reintroduction of extirpated species into areas they once inhabited has been an interest of wildlife managers for over half a century. Such reintroductions may occur by natural recolonization or human translocation of animals to selected sites. Elk (Cervus elaphus), once common throughout much of North America, have attracted particular interest. In recent years, proposals to reintroduce elk have been considered or implemented in Arkansas, Illinois, Kentucky, Minnesota, New York, Tennessee, Virginia, and Wisconsin (Van Deelen and others 1997; Witmer 1990). Establishment of elk into human-dominated landscapes requires a landscape-scale assessment of resource selection, which also is a necessary part of developing management plans that ensure availability of critical habitat and mitigation of potential conflicts. Previous studies of elk have provided useful information about habitat needs of elk, but have often focused on areas in the United States such as the Rocky Mountains or interior basins where impacts of human development were small when compared to the Great Plains and Midwest (e.g., Boyce and others 2003; Strohmeyer and others 1999). Habitat models developed in these areas seem appropriate for western populations, but may not be applicable to populations of elk in agro-forested areas (Cogan 1996). Geospatial information technologies frequently are used to characterize and evaluate wildlife habitat (Kobler and Adamic 2000; Osborne and others 2001; Radeloff and others 1999), however, insufficient attention has been directed at defining integrated procedures linking these tools to quantify resource selection by elk in agro-forested landscapes and establish rationale to create locally adapted management plans.

Elk were common throughout Nebraska during AngloEuropean exploration in the early 1800s (Fricke and others 2008). However, human settlement, introduction of ranching and agriculture, market and subsistence hunting, and habitat destruction led to extirpation of elk in the early $1880 \mathrm{~s}$ (Jones and others 1983). Rocky Mountain elk (C. e. nelsoni) reappeared in Nebraska via immigration in the 1960s, mainly in the Pine Ridge region of northwestern Nebraska (Fig. 1; Stillings 1999). Unlike their western counterparts (Thomas and others 1988), elk in Nebraska and most states east of the Rocky Mountains were located primarily on privately owned land (Cover 2000; Missouri Department of Conservation 2000; Stillings 1999). Elk in the Pine Ridge increased in numbers during the 1970s and 1980s, triggering complaints of damage to row crops and hay by local farmers and ranchers, which led to implementation of relatively liberal hunting seasons in the late 1980s. Approximately $86 \%$ of the elk in the Bordeaux Creek drainage near Chadron, Nebraska were removed during the 1986 and 1987 hunting seasons; in 198812 to 15 elk remained in the Bordeaux Creek area and hunting ceased. The number of elk in the Pine Ridge, however, continued to increase through the 1990s, which led to hunting seasons once again initiating in 1995 (Hygnstrom and others 2005).

In areas with intensive hunting, elk select habitat to minimize encounters with humans and this habitat is most often dense forest cover with low road densities (Burcham and others 1999). Thomas and others (1979) and Leckenby (1984) reported that adequate canopy cover for elk in the 
Blue Mountains of Oregon and Washington was $>50 \%$ and that good canopy cover was $>70 \%$. A debate ensued about whether elk select classes of cover for thermal regulation, hiding cover, or other reasons (Geist 1982; Peek and others 1982); however, evidence that elk selection is driven by forage has increased (Cook and others 1998). Resource use by elk in the Blue Mountains was greater near edges of cover $(<200 \mathrm{~m})$ than away from cover (Leckenby 1984). Elk in nonforested areas of southwestern Wyoming selected resources based on aspect and distance to road (Sawyer and others 2007).

The use of covariates similar to those used in mountainous regions and found in our agro-forest environment (Burcham and others 1999; Cover 2000; Sawyer and others 2007; Stillings 1999; Thomas and others 1988) provided a basis for developing resource selection functions for elk in northwestern Nebraska. Stillings (1999) and Cover (2000) gathered baseline data from 21 radio-collared female elk to identify 2 distinct herds in the Pine Ridge area with no apparent movement of elk between herds. From 1995 to 1997, Stillings (1999) and Cover (2000) observed 75-100 elk in each herd and estimated an average calf-cow ratio of 50:100 and bull-cow ratio of 40:100. They identified 4 human disturbance variables that influenced distribution of home ranges of female elk: agriculture, cattle, roads, and timber harvest. Results of these studies were the basis for identifying landscape-level variables that potentially influenced resource selection by female elk for our study. Our objectives were to determine characteristics of resources selected by female elk and identify publicly owned land within the Pine Ridge for potential redistribution of elk to reduce conflicts with landowners in the Pine Ridge region of northwestern Nebraska.

\section{Methods}

\section{Study Area}

The Pine Ridge is located in northwestern Nebraska, USA and is a mix of federal (3\%), state (3\%), and privately owned lands (94\%). Rural areas consisting of sparsely distributed farms and ranches dominate the landscape (0-0.28 houses $/ \mathrm{km}^{2}$; Stillings 1999). Two major state highways connect small communities $(<5500$ people) and many unpaved county roads traverse the study area. Elevations range from $940 \mathrm{~m}$ to $1590 \mathrm{~m}$ and slopes range from 0 to $54.5^{\circ}$; most of the study area $(87 \%)$ has slopes $<10^{\circ}$. Aspect is distributed unevenly when divided by class (north [39\%], south [17\%], east [21\%], west [22\%], and flat [1\%]). Climate is typical of semi-arid regions with average annual precipitation equaling $41 \mathrm{~cm}$, which mostly occurs in May and June (Western Regional Climate Center
[WRCC] 2007). Average annual high and low temperatures for the area are 17 and $1{ }^{\circ} \mathrm{C}$, respectively, from 1948 to 2007. Monthly low and high temperatures in the area are $-12^{\circ} \mathrm{C}$ in January and $32^{\circ} \mathrm{C}$ in July (WRCC 2007).

Land uses include livestock grazing, alfalfa, small grains production, logging, and recreational activities. Predominant landcovers in the Pine Ridge include mixed-grass prairies $\left(67 \%, 3240 \mathrm{~km}^{2}\right)$, ponderosa pine with $<70 \%$ canopy coverage $\left(12 \%, 599 \mathrm{~km}^{2}\right)$, and alfalfa $\left(7 \%, 330 \mathrm{~km}^{2}\right)$. Livestock production is a common occupation and the grazing season for cattle extends from about 15 May to 15 October with a typical stocking rate in the area of 1 animal unit month per ha. Agricultural fields (alfalfa and small grains production) occupy $15 \%$ of the study area $\left(714 \mathrm{~km}^{2}\right)$, average 16 ha in size, and are planted in semi-flat patches of open country between forested canyons or on flat areas near riparian areas (Cover 2000). Forests ( $>70 \%$ canopy coverage) and savannas ( $<70 \%$ canopy coverage) of ponderosa pine dominate the rugged limestone escarpments and hills $\left(806 \mathrm{~km}^{2}, 17 \%\right)$. Dominant herbaceous species found on exposed ridges and among savanna trees are little bluestem (Schizachyrium scorparium), blue grama (Bouteloua gracilis), hairy grama (B. hirsuta), sand bluestem (Andropogon hallii) and sedges (Carex spp.). Trees associated with canyon bottomlands and riparian areas commonly include American elm (Ulmus americana), cottonwood (Populus deltoides), green ash (Fraxinus pennsylvanica), and hackberry (Celtis occidentalis).

\section{Data}

\section{Elk Location Data}

We captured female elk and equipped them with numbered ear tags and mortality sensing $150-151 \mathrm{MHz}$ radio-collars (Advanced Telemetry Systems, Insanti, Minnesota, USA). We radio-collared only females because they were most numerous in the population and they likely determined most group movements and resource selection. We placed 10 collars on elk in the Bordeaux Creek area and 11 collars in the Hat Creek area. We located elk via radio-telemetry and visual observation from April 1995 to August 1997. We used two vehicles equipped with a 9-element Yagi directional antenna (Cushcraft, Keene, New Hampshire, USA) and a Telonics Model TR-2 receiver (Telonics, Mesa, Arizona, USA) and collected 2-3 azimuths within a 5-minute period for each location. Telemetry systems tests from true and estimated azimuths resulted in an average angular error of $\pm 1.9^{\circ}\left(\mathrm{SD}=0.54^{\circ}\right)$ at average distance between receiver and collar of $499 \mathrm{~m}$ (Lovallo and others 1994; VerCauteren and Hygnstrom 1998) and $\pm 2.6^{\circ}\left(\mathrm{SD}=12.1^{\circ}\right)$ at average distance between receiver and collar of $574 \mathrm{~m}$ (Gilsdorf and others 2008). We attempted to collect 1-3 locations per elk 
per week at various times of day and night to ensure data included resources selected (food and cover) during a complete 24-hour period. We discarded telemetry locations with associated error polygons $>10$ ha and filtered data to include only 1 location per elk per day to minimize temporal correlation within the data. We divided year into 5 seasons to measure seasonal differences in resource selection by elk. Seasons were pre-parturition (1 Mar-14 May), parturition (15 May-30 Jun), post-parturition (1 Jul-31 Aug), breeding (1 Sep-31 Oct), and post-breeding (1 Nov-28 Feb). The University of Nebraska Institutional Animal Care and Use Committee (IACUC \# 94-09-075) approved all methods of capture and handling of animals.

\section{Random Locations}

The Nebraska Game and Parks Commission (NGPC) defined the Pine Ridge of Nebraska as desirable habitat for elk and actively managed for a self-sustaining population (Menzel, K, NGPC, personal communication). Therefore, we assumed that the entire study site, other than urban areas, was potentially suitable habitat for elk. We calculated minimum and maximum daily displacement distances between consecutive locations for each radio-collared elk and used these distances to determine resources available to elk. We generated 5 random locations per use location, within the area defined to be available, to estimate differences between elk-use versus random sites. We assigned each set of 5 random locations and associated use location to the same strata (choice sets $=1$ use and 5 random locations). McFadden (1978) reported samples of this size would produce consistent results and Baasch and others (2010) found similar samples resulted in precise and accurate estimates of a known probability distribution. We did not generate random locations within $180 \mathrm{~m}$ of the use location to ensure these locations did not fall within the maximum acceptable error polygon (10 ha) associated with each use location.

\section{Development of GIS Coverages}

\section{Landcover}

We used Erdas Imagine 8.3 (ERDAS $^{\circledR}$, Inc., Atlanta, Georgia) to produce a landcover map using 1997 Landsat Thematic Mapper (TM) imagery. We used digital image processing techniques to generate a $30-\mathrm{m} \times 30-\mathrm{m}$ raster layer with 12 classes of landcover to be consistent with pixel size of other geospatial data layers. We identified 5 predominant classes of landcover as important to elk use: ponderosa pine with $>70 \%$ canopy cover, ponderosa pine with $<70 \%$ canopy cover, rangeland, row-crop agricultural land, and alfalfa. We combined riparian woodland $(<1 \%$ occurrence) with ponderosa pine containing $<70 \%$ canopy cover. Rangeland included lowland tall-grass prairie and western mixed-grass prairie. Row-crop agricultural land included fallow and small-grains agriculture. We re-classified all landcover identified as barren, sand, rocky outcrop, wetland, or open water to the nearest adjacent landcover because they included a small proportion of the total area $(<1 \%)$. We classified use and random locations for all covariate Geographical Information System (GIS) layers, including landcover, using the "Intersect Point Tool" in Hawth's Analysis Tools for ArcGIS (Beyer 2004; available at http://www.spatialecology.com/htools). We did not conduct a formal assessment of accuracy for classification of landcover due to the time lag between imagery collection (1997) and classification of locations (2007). We chose 1997 Landsat TM imagery to coincide with when elk locations were collected (April 1995 to August 1997). Forbes (2001), used a similar classification scheme and technique to create a landcover map for the same area and found a high degree of association between landcover classification and results of ground surveys.

\section{Distance to and Density of Roads}

We obtained a road GIS layer from United States Geological Survey (USGS) Digital Line Graph data (1:100,000 scale). We combined all road types, including paved highways, gravel roads, and 2-track roads. Traffic rates for all roads within the study area were not readily available. We applied a Euclidian distance function to the layer to generate a new raster representing distance to nearest road (m) for every pixel in the raster. We used a GIS to create a second road raster with a moving circular window (area equivalent to $1 \mathrm{~km}^{2}$ ) to sum all "road pixels" within the window and assigned the summed value of "road pixels" to the center pixel (Mace and others 1996; Summerfield and others 2004). We calculated road density for each raster cell in the study area on a pixel-by-pixel basis.

\section{Aspect and Slope}

We used a USGS digital elevation model $(1: 24,000)$ to calculate aspect and slope of resource units. Aspect ranged from 0 to $359^{\circ}$ with $0^{\circ}$ representing north. We converted aspect to a categorical variable with 5 classes: north $\left(315-359^{\circ}\right.$ and $\left.0-44^{\circ}\right)$, south $\left(135-224^{\circ}\right)$, east $\left(45-134^{\circ}\right)$, west $\left(225-314^{\circ}\right)$, and flat (cells with slope $=0.0)$. Degree of slope ranged from 0 to $90^{\circ}$ with $90^{\circ}$ representing vertical.

\section{Distance from Ponderosa Pine Edge}

We used the "Nearest Feature" extension in ArcView (Environmental Systems Research Institute, ArcView GIS 
Version 3.3. 1998, Redlands, California, USA) to calculate Euclidian distance of each use and random location into or out of cover areas (ponderosa pine with $>70 \%$ or $<70 \%$ canopy closure) from the landcover map. We entered distance from edge of ponderosa pine cover type into models as 2 separate variables, "distance in ponderosa pine" and "distance to ponderosa pine," which allowed us to discern differences in "edge-effects" when elk selected resources within and outside of patches of ponderosa pine.

\section{Resource Selection Modeling}

We selected covariates to include in our set of discretechoice models by identifying uncorrelated variables (pairwise $|r|<0.60$, McDonald and others 2006). The variables distance to road and road density were highly correlated ( $r=-0.76)$ so we only included distance to road in our set of models. We constructed a set of 31 models (Table 1) with variables: landcover (ponderosa pine with $>70 \%$ canopy cover, ponderosa pine with $<70 \%$ canopy cover, row-crop agricultural land, alfalfa, and rangeland [reference category $=$ ponderosa pine with $>70 \%$ canopy cover]), aspect (north, south, east, west, and flat [reference category $=$ east $]$ ), slope, distance to ponderosa pine, distance in ponderosa pine, and distance to road. Categorical variables landcover and aspect were converted to 'dummy' (0 or 1) variables within Program R; interpretation of coefficients are with respect to the reference category (coefficient $=0.0$ ). We included or excluded variables "distance to ponderosa pine" and "distance in ponderosa pine" as a group from the set of models to discern differences in effect of edge when elk selected resources within and outside cover of ponderosa pine. We tested all possible combinations of remaining variables to determine which, if any, were useful for determining resource selection by female elk in the Pine Ridge. We normalized data for all continuous variables $(\bar{X}=0, \mathrm{SE}=1)$ to improve model convergence and allow for direct comparisons of the level of effect for each variable across seasons.

We obtained estimates of coefficients by calculating conditional probabilities of use $\left(\hat{P}_{c}(i)\right)$ for selected resource units $(i)$ using the discrete-choice equation: $\hat{P}_{c}(i)=$ $\exp \left(\hat{\beta}_{1} x_{i 1}+\hat{\beta}_{2} x_{i 2}+\ldots+\hat{\beta}_{14} x_{i 14}\right) / \sum_{k \in\left\{U^{\prime} \cup A\right\}} \exp \left(\hat{\beta}_{1} x_{k 1}+\right.$ $\left.\hat{\beta}_{2} x_{k 2}+\ldots+\hat{\beta}_{14} x_{k 14}\right)$, where $x_{i j}$ was the covariate for the $i$ th resource unit, $U^{\prime}$ was the set of indices for unique used units, and $A$ was the set of indices for units in the random sample of units from the choice set (McDonald and others
Table 1 Thirty-one models used in discrete-choice analyses of resource selection by female elk in the Pine Ridge region of northwestern Nebraska, USA, 1995-1997

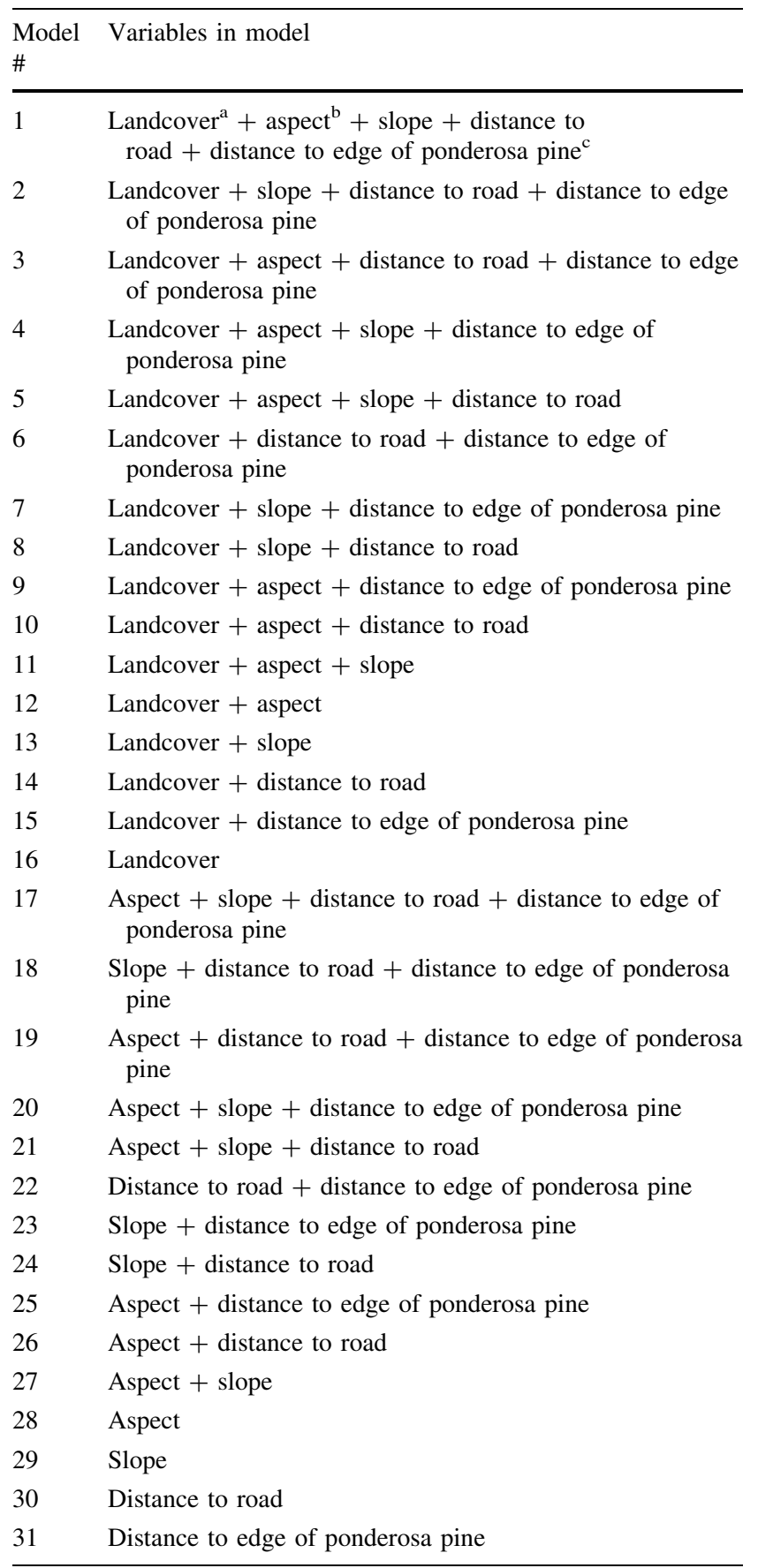

${ }^{a}$ Landcover was a categorical variable with 5 levels: ponderosa pine with $>70 \%$ canopy cover, ponderosa pine with $<70 \%$ canopy cover, rangeland, row-crop agricultural land, and alfalfa

b Aspect was a categorical variable with 5 levels: flat (slope $=0.0$ ), north, south, east, and west

c Distance to edge of ponderosa pine includes "distance to ponderosa pine" and "distance in ponderosa pine" 
2006). The equation assumed replacement of resource units after selection, which would allow elk to select a resource unit multiple times.

We initially subdivided data by herd to test for differences in resource selection between herds. We observed a high degree of similarity in resource selection between herds (i.e., all coefficients, except distance to ponderosa pine, were statistically indistinguishable). Elk in the Bordeaux and Hat Creek herds selected resources positioned near ponderosa pine cover types, but elk in the Bordeaux Creek herd had a higher affinity to ponderosa pine $(B=$ $-1.91 \pm 0.10$ and $B=-0.54 \pm 0.13$, respectively). We believe much of this difference was due to differences in size and distribution of ponderosa pine patches between herd areas. Due to similarities in discrete-choice models for each herd, we pooled data across herds for subsequent analyses and developed 1 model for each season for female elk in the Pine Ridge.

We used Cox proportional hazards regression function (COXPH) located in the "survival" package of Program R to develop our 31 discrete-choice models (R package version 2.31). We used information-theoretic methods (Burnham and Anderson 2002) with Bayesian Information Criterion (BIC) to rank the 31 models (Burnham and Anderson 2004). We calculated BIC scores, $\triangle B I C$ values, and BIC weights to determine weight-of-evidence for each model in the set. We considered models a candidate if they had a $\Delta$ BIC $\leq 6.0$ and recorded coefficients and standard errors for the most parsimonious of the candidate models (Richards 2008). We tested the assumption of independence of irrelevant alternatives when categorical variables were included in the final model by removing data associated with 2 levels of the categorical variable separately and combined (i.e., we removed locations classified as having a south-facing aspect, flat or no aspect, and south and flat aspects from our set of data) and observed resulting coefficients to ensure they did not change by removing these choice sets (Small and Hsiao 1985).

\section{Goodness-of-Fit}

To test goodness-of-fit of models, we used the discretechoice equation outlined in the preceding section to estimate the probability of use for all resource units (30$\mathrm{m} \times 30-\mathrm{m}$ raster cells) within the study area. We grouped resource units into 20 "bins" based on percentiles of estimated probabilities of resource use so that $5 \%$ of the resource units were in each bin (258,377 units/bin; Howlin and others 2004). We calculated predicted probabilities of use within each bin by summing estimated probabilities of use for all resource units within each bin (Howlin and others 2004). We calculated observed selection for each bin by calculating relative frequency of use for all resource units in each bin (number of use locations in each bin/total number of use locations collected during respective season). For example, if resource units A, B, and C are in bin 1 and 100 use locations were collected of which 3,7 , and 4 locations of use occurred on resource units $\mathrm{A}, \mathrm{B}$, and $\mathrm{C}$, respectively, the observed relative probability of selection for bin 1 would be $14 / 100$ or 0.14 .

We compared observed with predicted selection using a simple linear regression and used slope of regression models to measure predictive ability of discrete-choice models. Discrete-choice models that predicted use perfectly would have a slope and intercept coefficient from the linear regression model of 1.0 and 0.0 , respectively. We considered discrete choice models acceptable when the slope of linear regression models was not different from 1.0 (slope $\pm 1.96 \times \mathrm{SE}=1.0$ ). We determined there was a correlation between predicted and actual resource selection by elk when the slope of a regression-model was positive and $\neq 0$. In these cases, we observed data used in regressions to determine where predictions were inaccurate (resources with high, low, or all probabilities of use predicted poorly; Howlin and others 2004). We considered discrete choice models acceptable if we determined bins on outer margin of the probability distribution (bins 18-20) caused the lack of fit of regression lines due to leverage effects and the regression line fit remaining data.

\section{Classification of Resource Selection}

We used final models and a parametric bootstrapping procedure to assess the proportion of resource units in the study area, herd areas, and a potential elk redistribution area with characteristics selected by female elk on a seasonal basis. We determined the potential elk redistribution area should contain resource units with characteristics selected by elk in other areas of the Pine Ridge and a higher proportion of publicly owned land than observed in the existing herd areas. We used the "mvrnorm" function located in the MASS package of program $\mathrm{R}$ where $\mu=$ coefficients of the final models and $\sigma=$ variancecovariance matrix for each model to produce 1000 models for each of the 5 seasons. We estimated the probability of use for all resource units within the study area and divided resource units from the 1000 models into 2 classes of seasonal selection: high and low. We classified all resource units with probabilities of selection above what would be observed if selection of resource units by female elk occurred randomly across the study area (i.e., 1/total number of resource units in the study area or $1 / 5,167,536$ ), as high seasonal selection and classified the remaining resources as low. We reported the mean proportion of resource units in the study area, herd areas, and potential elk redistribution area classified as high seasonal selection 
and the 0.025 and 0.975 quantiles (95\% confidence limits $\left[\mathrm{CI}_{95}\right]$ ) from the 1000 bootstrap simulations.

We used seasonal discrete-choice models to calculate probabilities of selection of resource units by female elk during at least 1 of the 5 seasons $\left(\hat{P}_{(\text {annual })}\right)$ using: $\hat{P}_{(\text {annual })}=1-\left(\left[1-\hat{P}(i)_{S 1}\right] \times\left[1-\hat{P}(i)_{S 2}\right] \times\left[1-\hat{P}(i)_{S 3}\right] \times\right.$ $\left.\left[1-\hat{P}(i)_{S 4}\right] \times\left[1-\hat{P}(i)_{S 5}\right]\right)$, where $\hat{P}(i)_{S x}$ were seasonspecific estimated probabilities of resource use. Similar to seasonal models, we scaled $\hat{P}_{(\text {annual })}$ to sum to 1.0 . We divided resource units into 3 classes of selection: high, moderately high, and low. We classified all resource units with an annual probability of selection $\left(\hat{P}_{(\text {annual })}\right)>90$ th percentile as high. We classified the remaining resource units with probabilities of selection above or below what would be observed if selection of resource units occurred randomly across the study area $(1 / 5,167,536)$, as moderately high or low, respectively. We used a GIS to observe the distribution of classes of probabilities of resource selection by female elk and to identify a potential area in the Pine Ridge in which elk could be redistributed.

\section{Results}

Data

We collected 3011 and 2776 locations from 21 female elk (10-15\% of the population) in the Bordeaux and Hat Creek areas, respectively, during all periods of the day $(0301-0900=35 \%, \quad 0901-1500=31 \%, \quad 1501-2100=$ $21 \%, 2101-0300=13 \%$ ). The Bordeaux and Hat Creek herds occupied areas of 435 and $417 \mathrm{~km}^{2}$ (estimated using $100 \%$ minimum convex polygon), respectively, of which a majority of the land was privately owned ( $87 \%$ and $84 \%$, respectively). When multiple observations of an elk occurred on a single day, we randomly selected 1 of the observations to include in the analyses, which resulted in 5013 elk-use locations to analyze (2679 and 2334 for Bordeaux and Hat Creek herds, respectively). Average maximum daily displacement for all radio-collared elk was 10,076 m (Range $=2780 \mathrm{~m}$ to $24,644 \mathrm{~m}$ ). We found 17 of 21 radiocollared female elk $(81 \%)$ traveled $>7500 \mathrm{~m}$ in a $24-\mathrm{h}$ period and assumed the others could have as well if they so desired. We generated 25,065 random locations for female elk within a 180-7500-m buffer of respective use locations.

\section{Resource Selection Modeling}

The resource selection discrete-choice model that ranked highest for pre-parturition season $(\mathrm{BIC}$-weight $=0.9502$ ) included slope + distance to road + distance to edge of ponderosa pine (Table 2). The highest-ranking model for
Table 2 Candidate $(\triangle \mathrm{BIC} \leq 6.0)$ discrete-choice models (ranked by BIC) used to estimate probability of female elk selecting $30-\mathrm{m} \times 30$ $\mathrm{m}$ resource units, including the number of parameters in each model (K), BIC, $\triangle \mathrm{BIC}$, and BIC-weights during 5 seasons in the Pine Ridge region of northwestern Nebraska, USA, 1995-1997

\begin{tabular}{lccccc}
\hline Season $^{\text {a }}$ & Model \# & K & BIC & $\Delta$ BIC & Weight \\
\hline Pre-parturition & 18 & 4 & 3223.63 & 0.00 & 0.9502 \\
Parturition & 2 & 8 & 3229.55 & 5.92 & 0.0492 \\
& 31 & 2 & 2197.83 & 0.00 & 0.8053 \\
Post-parturition & 23 & 3 & 2201.36 & 3.53 & 0.1378 \\
& 22 & 3 & 2203.42 & 5.59 & 0.0492 \\
& 22 & 2 & 1992.05 & 0.00 & 0.4632 \\
Breeding & 18 & 4 & 1996.27 & 4.22 & 0.0562 \\
& 23 & 3 & 1997.09 & 5.04 & 0.0373 \\
Post-breeding & 22 & 3 & 2831.19 & 0.00 & 0.7072 \\
& 18 & 4 & 2833.01 & 1.82 & 0.2847 \\
& 20 & 6 & 5332.92 & 0.00 & 0.7451 \\
& 17 & 7 & 5335.08 & 2.16 & 0.2530 \\
\hline
\end{tabular}

${ }^{a}$ Biological seasons including pre-parturition (1 Mar-14 May), parturition (15 May-30 Jun), post-parturition (1 Jul-31 Aug), breeding (1 Sep-31 Oct), and post-breeding (1 Nov-28 Feb)

parturition season $(\mathrm{BIC}$-weight $=0.8053)$ included distance to edge of ponderosa pine (Table 2). Discrete-choice modeling identified two models with similar weight-ofevidence for post-parturition season: distance to edge of ponderosa pine $(\mathrm{BIC}$-weight $=0.4632)$ and distance to road + distance to edge of ponderosa pine (BICweight $=0.4384$; Table 2 ). The highest-ranking models for breeding and post-breeding seasons included distance to road + distance to edge of ponderosa pine (BIC-weight $=$ 0.7072) and aspect + slope + distance to edge of ponderosa pine $($ BIC-weight $=0.7451)$, respectively $($ Table 2$)$. Coefficients of our final model during the post-breeding season (model 20; Table 1) did not change when we removed choice sets that contained use or random locations classified as having: (1) a south facing aspect; (2) no aspect (flat); nor (3) when we removed choice sets that contained locations with either south-facing or flat aspects $(P<0.05)$.

\section{Goodness-of-Fit}

All season-specific models provided good predictions of resource selection by female elk in the Pine Ridge (Fig. 2), however, re-substitution methods as employed in our study tend to result in optimistic measures of predictive success (Fielding and Bell 1997). The slope of the regression line for all models was $>0.0$ and all confidence intervals for these slopes contained 1.0 (Slope $\pm 1.96 \times \mathrm{SE}=1.0$ ), which indicated high correlation between observed and predicted selection of resources by female elk (i.e., good fit of models to data). 

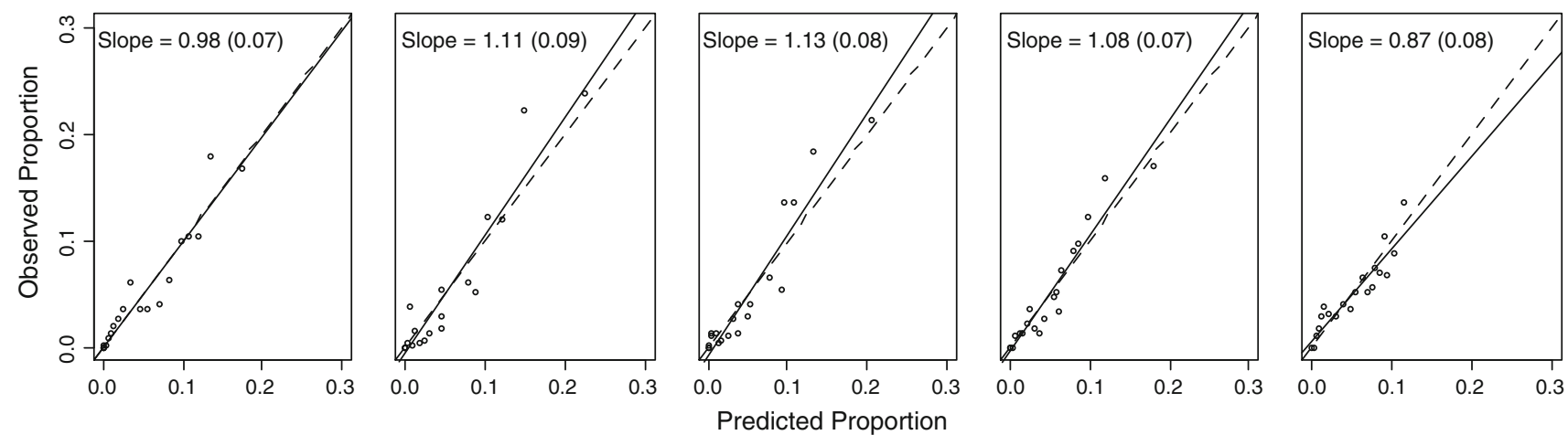

Fig. 2 Goodness-of-fit regressions predicting observed selection with estimates predicted by discrete-choice models generated for female elk in the Pine Ridge region of northwestern Nebraska, USA during pre-parturition, parturition, post-parturition, breeding, and postbreeding seasons (left to right), 1995 to 1997. Plots include observed versus predicted proportions of resource-use (points), a regression of

proportions (solid line), $X=Y$-line (dashed line), and slope of regression line with standard error in parenthesis. A slope of 1 indicates a one-to-one relationship between observed and predicted proportions of resource selection (i.e., good fit of model to locations of female elk)

Table 3 Coefficients and standard errors (in parenthesis) of discrete-choice models used to estimate probability of female elk selecting 30$\mathrm{m} \times$ 30-m resource units within the Pine Ridge region of northwestern Nebraska, USA during 5 seasons, 1995-1997

\begin{tabular}{|c|c|c|c|c|c|c|c|}
\hline Season & & & Variables $^{\mathrm{a}}$ & & & & \\
\hline \multicolumn{8}{|c|}{ Pre-parturition (1 Mar-14 May) } \\
\hline Flat & North & South & West & Slope & DtoRd & DtoPP & DinPP \\
\hline$-{ }^{\mathrm{b}}$ & - & - & - & $0.24(0.04)$ & $0.17(0.04)$ & $-1.71(0.15)$ & $-0.04(0.04)$ \\
\hline \multicolumn{8}{|c|}{ Parturition (15 May-30 Jun) } \\
\hline Flat & North & South & West & Slope & DtoRd & DtoPP & DinPP \\
\hline- & - & - & - & - & - & $-2.62(0.23)$ & $0.30(0.04)$ \\
\hline \multicolumn{8}{|c|}{ Post-Parturition (1 Jul-31 Aug) } \\
\hline Flat & North & South & West & Slope & DtoRd & DtoPP & DinPP \\
\hline- & - & - & - & - & - & $-1.88(0.18)$ & $0.31(0.04)$ \\
\hline \multicolumn{8}{|c|}{ Breeding (1 Sep-31 Oct) } \\
\hline Flat & North & South & West & Slope & DtoRd & DtoPP & DinPP \\
\hline- & - & - & - & - & $0.16(0.04)$ & $-1.32(0.12)$ & $0.21(0.03)$ \\
\hline \multicolumn{8}{|c|}{ Post-Breeding (1 Nov-28 Feb) } \\
\hline Flat & North & South & West & Slope & DtoRd & DtoPP & DinPP \\
\hline$-2.30(1.01)$ & $0.19(0.07)$ & $-0.23(0.09)$ & $-0.14(0.08)$ & $0.28(0.03)$ & - & $-0.71(0.07)$ & $-0.21(0.04)$ \\
\hline
\end{tabular}

${ }^{a}$ Habitat variables included in the final discrete-choice models including: aspect (Flat [slope $=0.0$ ], North, South, West, and reference category East [not included]), distance to road [DtoRd], distance to ponderosa pine cover type [DtoPP], and distance in ponderosa pine cover type [DinPP]

b Indicates variables not included in the seasonal discrete-choice model

\section{Resource Selection in the Pine Ridge}

Distance of resource units from edge of ponderosa pine cover types had the greatest influence on seasonal selection of resources by female elk in the Pine Ridge (Table 3). Female elk selected resources positioned near or within patches of ponderosa pine during all seasons. When selecting resources positioned outside of patches of ponderosa pine, female elk had strongest association to ponderosa pine cover types during parturition season and were most likely to select resources positioned away from forested areas following breeding season. Female elk selected resource units located away from edge (farther in forest) when selecting resources within ponderosa pine forests during parturition, post-parturition, and breeding seasons. However, female elk selected resources positioned near the edge when selection occurred within patches of ponderosa pine during post-breeding season.

In addition to distance from edge of ponderosa pine cover types, distance to road, slope, and aspect were seasonally important factors in determining selection of resources by female elk (Table 3). Female elk selected resources positioned away from roads during pre-parturition and breeding seasons. Female elk also selected areas 
with greater slopes during winter (post-breeding and preparturition seasons). Aspect did not influence selection of resources during most seasons, but did during post-breeding season. Female elk selected resources with north- and east-facing aspects over those with a south-facing aspect and resources with no slope (flat).

\section{Classification of Resource Selection}

On average, female elk selected characteristics of $42 \%$ of the resource units in the study area during each season $\left(1952 \mathrm{~km}^{2}\right.$, range $\left.=1687-2360 \mathrm{~km}^{2}\right)$. Female elk selected resources on a broader scale during post-breeding $\left(2360 \mathrm{~km}^{2}, \mathrm{CI}_{95}=2281-2440 \mathrm{~km}^{2}\right)$ than other seasons of the year. By parturition season, the specificity in which female elk selected resources increased greatly $\left(1687 \mathrm{~km}^{2}\right.$, $\mathrm{CI}_{95}=1603-1770 \mathrm{~km}^{2}$ ). The highest probabilities of resource selection by female elk tended to be in areas within $200 \mathrm{~m}$ of ponderosa pine and in areas with a slope $\geq 10 \%$.

On an annual basis (probability of resource selection during $\geq 1$ season), female elk selected characteristics of $42 \%$ of the landcover in the Pine Ridge $\left(1946 \mathrm{~km}^{2}\right.$, $\mathrm{CI}_{95}=1907-1984 \mathrm{~km}^{2}$ ). A majority of the landcover with characteristics highly selected for by female elk (probability of selection $>90$ th percentile) were located near or within patches of ponderosa pine. Female elk selected characteristics of $67 \%\left(292 \mathrm{~km}^{2}, \mathrm{CI}_{95}=289-296 \mathrm{~km}^{2}\right)$ and $56 \%$ $\left(233 \mathrm{~km}^{2}, \mathrm{CI}_{95}=229-237 \mathrm{~km}^{2}\right)$ of the landcover in the Bordeaux Creek and Hat Creek areas, respectively. Ninety-one percent of the landcover in the potential elk redistribution area $\left(149 \mathrm{~km}^{2}, \mathrm{CI}_{95}=145-152 \mathrm{~km}^{2}\right)$ had characteristics that female elk selected for in the current herd areas (Fig. 3). Forty-nine percent of the landcover $\left(80 \pm 1 \mathrm{~km}^{2}\right)$ with a high or moderately high probability of selection by female elk within the potential elk redistribution area was on publicly owned land versus $<18 \%$ for the Bordeaux $\left(52 \pm 1 \mathrm{~km}^{2}\right)$ and Hat Creek areas $\left(41 \pm 1 \mathrm{~km}^{2}\right)$.

\section{Discussion}

Previous studies indicated elk select resources based on slope and proximity of roads and wooded cover (Boyce and others 2003; Millspaugh and others 1998; Rowland and others 2000; Stubblefield and others 2006). The factor that had greatest influence on resource selection by elk in the Pine Ridge was distance to ponderosa pine cover types. Female elk displayed the highest affinity for patches of ponderosa pine during spring and summer months. Elk also selected resources positioned farther into ponderosa pine cover types during these seasons, likely for concealed foraging opportunities or for escape and hiding cover. Selection of calving areas within cover may reduce vulnerability of calves to predation and, while near the edge,

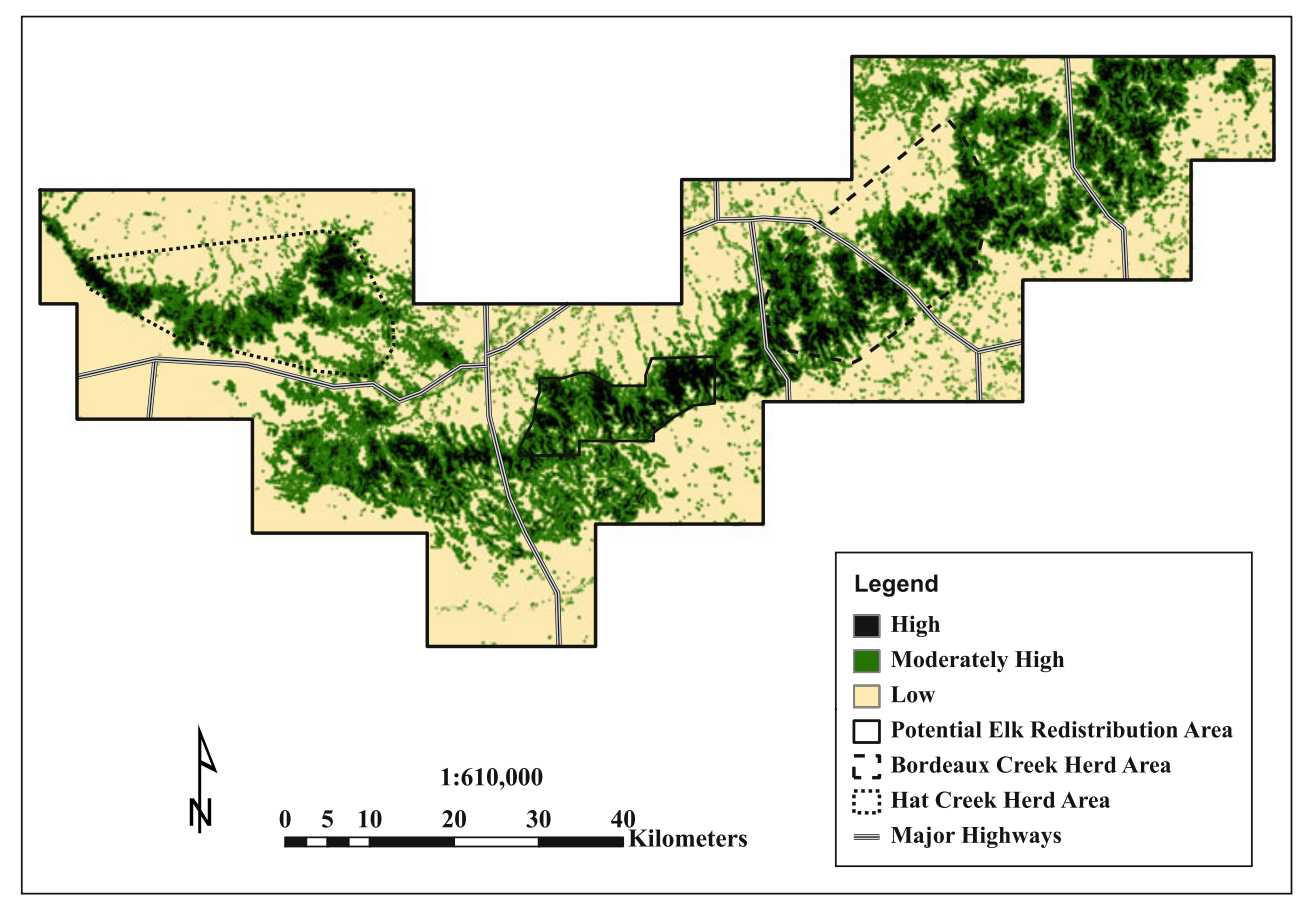

Fig. 3 Distribution of classes of joint probabilities of resource selection for female elk in the Pine Ridge region of Northwestern Nebraska, USA based on 5 seasonal discrete-choice models. Classes included: High ( $>90$ th percentile), Moderately High (>random and
$<90$ th percentile), and Low ( $<$ random). We also identified a potential elk redistribution area based on resources with moderately-high or high probabilities of selection and a preponderance of publically owned land 
increase access to vital food resources for cows during pregnancy and lactation (Stillings 1999). Stillings (1999) also found that female elk in the Pine Ridge selected areas for calving with slightly more over-story canopy coverage $(\bar{X}=70 \%$, range $=52-90 \%)$ and more hiding cover than randomly located sites $(\bar{X}=66 \%$, range $=0-89 \%)$. In Oregon and Washington, the majority of elk-use occurred near the edge of cover in foraging areas and at greater distances to the edge when within cover areas (Witmer and others 1985). Elk in a nonforested area in southwestern Wyoming also selected for areas of cover provided by shrubby vegetation (Sawyer and others 2007). Ponderosa pine forest may provide shade for cows and newborn calves during periods of warmer weather, which could reduce heat-stress and water intake requirements of lactating elk (Millspaugh and others 1998).

Many studies associated with reintroduction of elk in areas east of the Rocky Mountains, USA related presence of hunting with an avoidance of roads by elk (Didier and Porter 1999; Missouri Department of Conservation 2000; Telesco and others 2007). Avoidance of roads by elk, however, is often dependent on amount of vehicular traffic, density of cover, acclimation of elk to human disturbances, and past hunting practices in the area (Millspaugh and others 1998; Sawyer 1997; Wisdom and others 2004). In western Montana, hunting pressure resulted in an increased use of privately owned land by elk for refuge during hunting seasons, long-term establishments of elk on these lands, and increased conflicts with landowners (Burcham and others 1999). The intensity of hunting in the Pine Ridge was considered low during our study. From 1995 to 1998, 57 and 38 elk were harvested in the Bordeaux and Hat Creek areas, respectively (Stillings 1999). Distance to roads did not influence selection of resources by female elk in the Pine Ridge during parturition, post-parturition, and post-breeding seasons. Similarly, elk did not exhibit an avoidance of roads in South Dakota or Wisconsin (Anderson and others 2005; Millspaugh and others 1998; Millspaugh 1999). Our study indicated that in the presence of low hunting pressure, roads may not influence selection of resources by elk as much as they do in other areas. Many low use roads (i.e. 2-track) that traversed our study area, however, were located between patches of ponderosa pine and cropland where elk had adequate cover and could increase forage intake while reducing energy expenditures to obtain food (Anderson and others 2005; Wisdom and others 1986). The juxtaposition of ponderosa pine, roads, and crops provided elk forage (crops, roadside grasses, and forbs), edge, and immediate access to cover, which potentially reduced avoidance of these areas (Anderson and others 2005). We attribute the lack of avoidance of roads by elk in the Pine Ridge to acclimation to human-disturbance, absence of high-intensity hunting, and juxtaposition of roads, agricultural cropland, and ponderosa pine cover types.

Elk in the Pine Ridge selected north- and avoided southfacing slopes during winter. Contrary to our findings, elk in a mountainous region of Idaho and nonforested areas of southwestern Wyoming selected south-facing slopes during winter and north-facing slopes during summer (Sawyer and others 2007; Unsworth and others 1998). Regional differences in winter severity and snow depth may have caused this difference in selection. Elk in central and eastern United States typically experience less snowfall and higher mean temperatures than western elk and thus may experience less variability in snow cover between north- and south-facing slopes (Wichrowski and others 2005). In western Nebraska, cool-season grasses were highly associated with north-facing slopes and warm-season grasses were more likely to be associated with south-facing slopes in west-central Nebraska (Schacht and others 2000). Differences in composition and availability of cool- and warm-season grasses associated with north- and southfacing slopes following fall-growth of cool-season grasses may have influenced selection of resources by elk in our study area.

Elk selected steeper slopes during winter and early spring. Selection of certain slopes by elk may be determined by microclimate, plant composition, decreased accessibility of humans due to steepness, routes of escaping predators, and ease of movement by using upper slopes and ridge tops for travel (Skovlin 1982). Similar to our findings, female elk in British Columbia and Ontario Canada selected areas with greater slope and had a lower affiliation to cover during winter months (Jenkins and others 2007; Poole and Mowat 2005). The more open terrain may have provided elk more foraging opportunities than densely forested areas during winter. Slope of resource units, however, was not important in determining selection by female elk in our study area during other seasons. Elk in Wyoming on the Bighorn National Forest selected areas with slopes of $10-30^{\circ}$, with use of habitat by elk quickly decreasing with slopes $>30^{\circ}$ (Sawyer 1997). Stillings (1999) found mean slope of calving sites in the Pine Ridge was $11^{\circ}$ and that steeper slopes (range $=12-29^{\circ}$ ) often surrounded calving sites. A confounding factor to the slope predictor variable though, was that most of the steeper slopes used by elk in the Pine Ridge were also covered by ponderosa pine forest. Steep slopes have deterred landowners from cutting trees and turning areas into agricultural fields. We acknowledge that areas of ponderosa pine forest were positively correlated with slope and that they were linked in resource-use by elk, however, not all areas with slopes $>10^{\circ}$ were covered in ponderosa-pine. In addition, slope and distances to and in ponderosa pine were 
only moderately correlated $(r=-0.41$ and $r=0.24$, respectively).

Results from our landscape-level GIS-based study indicate the Pine Ridge region of Nebraska was composed of seasonal minima and maxima landcover with characteristics selected by female elk during parturition $\left(1687 \mathrm{~km}^{2}\right)$ and post-breeding seasons $\left(2360 \mathrm{~km}^{2}\right)$, respectively. Similar to elk in Michigan (Beyer 1987), the reduced availability of food during winter appeared to decrease specificity in which elk selected resources in our study area. The $>25 \%$ decline in area selected by female elk during parturition season was most likely related to the reduced mobility of females when calving and rearing young and increased availability of forage during spring green-up. If models from data collected within the Bordeaux and Hat Creek areas of the Pine Ridge are applicable to other areas within the Pine Ridge, we believe the potential elk redistribution area we identified (Fig. 3) could accommodate elk year-round.

The potential elk redistribution area consisted of $163 \mathrm{~km}^{2}$ of land of which the National Forest Service and NGPC owned 70 and $15 \mathrm{~km}^{2}$, respectively. The potential elk redistribution area encompassed $<4 \%$ of the Pine Ridge, but comprised $8 \%$ of the resource units with characteristics selected for by female elk. We classified $91 \%$ of the total landcover $\left(163 \mathrm{~km}^{2}\right)$ and $96 \%$ of the public land within the potential elk redistribution area $\left(83 \mathrm{~km}^{2}\right)$ as having landscape characteristics selected by elk in adjacent areas of the Pine Ridge. Acquisition of associated tracts of land to make a contiguous block of publicly owned land in this area might reduce conflicts between elk and private landowners and maximize probability of sustaining a larger population of elk annually. Elk could be hazed off adjacent privately owned areas where they are causing damage or are not appreciated. The use of fire, fertilizer, water, and even livestock grazing could make the publicly owned land in the potential elk redistribution area more attractive to elk (Peek and others 2001; Poole and Mowat 2005). Public ownership of land also increases the ability to limit access for hunting to areas on the periphery of this area, which could also relate to a refugia-effect and higher fidelity by elk. Studies of elk behavior suggest that repeated disturbances during the hunting season resulted in elk selecting alternative areas until they were no longer disturbed (Bryant and others 1991; Lyon and Canfield 1991). In absence of intensive hunting, it appears that elk predominantly would occupy publicly owned land within this area, which would reduce competition with livestock and crop depredation. Increased use of publicly owned land may also increase acceptance of elk in the area, which could allow for more elk in the Pine Ridge area of Nebraska.

\section{Conclusions and Management Implications}

Most studies that relate elk to resources and guidelines for managing elk have been developed in mountainous regions of western USA. Our data, however, show that selection of resources by elk in agro-forest landscapes was different from the intermountain west, with the most notable difference being a lack of avoidance of roads. Recent proposals to introduce elk into privately owned agro-forested areas east of the Rocky Mountains necessitate an identification of important characteristics of elk habitat in these areas. Studies in areas such as the Pine Ridge provide valuable information for managers in similar agro-forested areas. We used our models to identify a potential elk redistribution area and recently discovered that elk have naturally recolonized this area and appear to be thriving (T. Nordeen, NGPC, personal communication). Through management practices and other methods discussed, elk in the potential elk redistribution area may occupy publicly owned land and become a more socially accepted species by private landowners in the area. We propose basing management plans for elk in agro-forested landscapes on elk behavior in areas of similar land-use practices. Our study demonstrates how geospatial information technologies and spatial modeling can be used to aid development of landscape-level and locally adapted management plans for elk in an agro-forested landscape. In addition, because variables were easy to measure and introductions of elk into privately owned, agro-forested landscapes are likely to continue, our model lends itself to application and validation in these regions.

Acknowledgments The authors thank M. Cover, D. Crank, and B. Stillings for data collection. We thank landowners in the Pine Ridge that allowed access to their land to conduct research. The Nebraska Gap Analysis Project, Nebraska Game and Parks Commission, University of Nebraska-Lincoln, Nebraska National Forest, Rocky Mountain Elk Foundation, and USDA/APHIS/WS/National Wildlife Research Center provided funding for this project.

\section{References}

Anderson DP, Turner MG, Forester JD, Zhu J, Boyce MS, Beyer H, Stowell L (2005) Scale-dependent summer resource selection by reintroduced elk in Wisconsin, USA. Journal of Wildlife Management 69:298-310

Baasch DM, Tyre AJ, Millspaugh JJ, Hygnstrom SE, VerCauteren KC (2010) An evaluation of three statistical methods used to model resource selection. Ecological Modeling 221:565-574

Beyer DE (1987) Population and habitat management of elk in Michigan. Dissertation, Michigan State University, East Lansing, USA

Boyce MS, Turner MG, Fryxell J, Turchin P (2003) Scale and heterogeneity in habitat selection by elk in Yellowstone National Park. Ecoscience 10:421-431

Bryant LD, Thomas JW, Johnson BK, Noyes JH (1991) Hunter and Rocky Mountain elk (Cervus elaphus nelsoni) interactions in the 
Starkey Experimental Forest and Range. In: Christensen AG, Lyon LJ, Lonner TN (eds) Proceedings of the Elk vulnerability symposium. Montana State University, Bozeman, USA, pp 168-173

Burcham M, Edge WD, Marcum CL (1999) Elk use of private land refuges. Wildlife Society Bulletin 27:833-839

Burnham KP, Anderson DR (2002) Model selection and multi-model inference: a practical information-theoretic approach, 2nd edn. Springer-Verlag, New York, New York, USA

Burnham KP, Anderson DR (2004) Multimodel inference: understanding AIC and BIC in model selection. Sociological Methods and Inference 33:261-304

Cogan RD (1996) Management plan for elk in Pennsylvania. Bureau of Wildlife Management, Pennsylvania Game Commission, Harrisburg, Pennsylvania, USA

Cook JG, Irwin LL, Bryant LD, Riggs RA, Thomas JW (1998) Relations of forest cover and condition of elk: a test of the thermal cover hypothesis in summer and winter. Wildlife Monograph No. 141

Cover M (2000) Ecology of elk in the Pine Ridge of Northwestern Nebraska: seasonal distribution, characteristics of wintering sites, and herd health. Thesis, University of Nebraska, Lincoln, USA

Didier KA, Porter WF (1999) Large-scale assessment of potential habitat to restore elk to New York State. Wildlife Society Bulletin 27:409-418

Fielding AH, Bell JF (1997) A review of methods for the assessment of prediction errors in conservation presence/absence models. Environmental Conservation 24:38-49

Forbes KM (2001) Modeling big horn sheep habitat in northwest Nebraska. Thesis, University of Nebraska, Lincoln, USA

Fricke KA, Cover MA, Hygnstrom SE, Groepper SR, Genoways HH, Hams KM, VerCauteren KC (2008) Historic and recent distributions of elk in Nebraska. Great Plains Research 18:189-204

Geist V (1982) Adaptive behavioral strategies. In: Thomas JW, Toweill DE (eds) Elk of North America-ecology and management. Stackpole Books, Harrisburg, Pennsylvania, USA, pp 219-277

Howlin S, Erickson WP, Neilson RM (2004) A validation technique for assessing predictive abilities of resource selection functions. In: Huzurbazar S (ed) Resource selection methods and applications. Omnipress, Madison, Wisconsin, USA, pp 40-51

Hygnstrom SE, Cover MA, Stillings BA, Crank RD, Fischer JW, Merchant JW, Korte SP (2005) Elk in Nebraska: opportunity or another private-public land conundrum. Proceedings of the Wildlife Damage Management Conference 11:213-218

Jenkins DA, Schaefer JA, Rosatte R, Bellhouse T, Hamr J, Mallory FF (2007) Winter resource selection of reintroduced elk and sympatric white-tailed deer at multiple spatial scales. Journal of Mammalogy 88:614-624

Jones JK Jr, Armstrong DM, Hoffman RS, Jones C (1983) Mammals of the Northern Great Plains. University of Nebraska Press, Lincoln, USA

Kobler A, Adamic M (2000) Identifying brown bear habitat by a combined GIS and machine learning method. Ecological Modeling 135:291-300

Leckenby DA (1984) Elk use and availability of cover and forage habitat components in the Blue Mountains, Northeast Oregon, 1976-1982. Wildlife Research Report Number 14, Oregon Department of Fish and Wildlife, Salem, USA

Lyon LJ, Canfield JE (1991) Habitat selections by Rocky Mountain elk under hunting season stress. In: Christensen AG, Lyon LJ, Lonner TN (eds) Proceedings of the Elk vulnerability symposium. Montana State University, Bozeman, USA, pp 99-105

Mace RD, Waller JS, Manley TL, Lyon LJ, Zuuring H (1996) Relationships among grizzly bears, roads, and habitat in the
Swan Mountains, Montana. Journal of Applied Ecology 33: 1395-1404

McDonald TL, Manly BFJ, Nielson RM, Diller LV (2006) Discretechoice modeling in wildlife studies exemplified by northern spotted owl nighttime habitat selection. Journal of Wildlife Management 70:375-383

McFadden D (1978) Modeling the choice of residential location. In: Karlquist A, Lundqvist L, Snickars F, Weibull J (eds) Spatial interaction theory and planning models. North Holland Publishing Company, Amsterdam, The Netherlands, pp 75-96

Millspaugh JJ (1999) Behavioral and physiological responses of elk to human disturbances in the southern Black Hills, South Dakota. Dissertation, University of Washington, Seattle, USA

Millspaugh JJ, Raedeke KJ, Brundige GC, Willmott CC (1998) Summer bed sites of elk (Cervus elaphus) in the Black Hills, South Dakota: considerations for thermal cover management. American Midland Naturalist 139:133-140

Missouri Department of Conservation (2000) Missouri elk reintroduction feasibility study. Missouri Department of Conservation, Jefferson City, USA

Osborne PE, Alonso JC, Bryant RG (2001) Modelling landscapescale habitat use using GIS and remote sensing: a case study with great bustards. Journal of Applied Ecology 38:458-471

Peek JM, Scott MD, Nelson LJ, Peirce DJ, Irwin LL (1982) The role of cover in habitat management in Northwestern United States. Transactions of the North American Wildlife Natural Resources Conference 47:363-373

Peek JM, Korol JJ, Gay D, Hershey T (2001) Overstory-understory biomass changes over a 35-year period in southcentral Oregon. Forest Ecology and Management 150:267-277

Poole KG, Mowat G (2005) Winter habitat relationships of deer and elk in the temperate interior mountains of British Columbia. Wildlife Society Bulletin 33:1288-1302

Radeloff VC, Pidgeon AM, Hostert P (1999) Habitat and population modeling of roe deer using an interactive geographic information system. Ecological Modeling 114:287-304

Richards SA (2008) Dealing with overdispersed count data in applied ecology. Journal of Applied Ecology 45:218-227

Rowland MM, Wisdom MJ, Johnson BK, Kie JG (2000) Elk distribution and modeling in relation to roads. Journal of Wildlife Management 64:672-684

Sawyer HH (1997) Evaluation of a summer elk model and sexual segregation of elk in the Bighorn Mountains, Wyoming. Thesis, University of Wyoming, Laramie, USA

Sawyer H, Nielson RM, Lindzey FG, Keith L, Powell JH, Abraham AA (2007) Habitat selection of Rocky Mountain elk in a nonforested environment. Journal of Wildlife Management $71: 868-874$

Schacht WH, Volesky JD, Bauer D, Smart AJ, Mousel EM (2000) Plant community patterns on upland prairie in the eastern Nebraska sandhills. The Prairie Naturalist 32:43-58

Skovlin JM (1982) Habitat requirements and evaluations. In: Thomas JW, Toweill DE (eds) Elk of North America: ecology and management. Stackpole Books, Harrisburg, Pennsylvania, USA, pp 369-413

Small KA, Hsiao C (1985) Multinomial logit specification test. International Economic Review 26:619-627

Stillings B (1999) Ecology of elk in northwestern Nebraska: demographics, effects of human disturbance, and characteristics of calving habitat. Thesis, University of Nebraska, Lincoln, USA

Strohmeyer DC, Peek JM, Bowlin TR (1999) Wapiti bed sites in Idaho sagebrush steppe. Wildlife Society Bulletin 27:547-551

Stubblefield CH, Vierling KT, Rumble MA (2006) Landscape-scale attributes of elk centers of activity in the central Black Hills of South Dakota. Journal of Wildlife Management 70:1060-1069 
Summerfield B, Johnson W, Roberts D (2004) Trends in road development and access management in the Cabinet-Yaak and Selkirk grizzly bear Recovery Zones. Ursus 15:115-122

Telesco RL, Van Manen FT, Clark JD, Cartwright ME (2007) Identifying sites for elk restoration in Arkansas. Journal of Wildlife Management 71:1393-1403

Thomas JW, Black H Jr, Scherzinger RJ, Pedersen RJ (1979) Deer and elk. In: Thomas JW (ed) Wildlife habitats in managed forests the Blue Mountains of Oregon and Washington. United States Department of Agriculture. Agricultural Handbook 553, Washington, D.C., USA, pp 104-127

Thomas JW, Leckenby DA, Lyon LJ, Hicks LL, Marcum CL (1988) Integrated management of timber-elk-cattle: interior forest of western North America, General Technical Report PNW-GTR225. U.S. Forest Service, Pacific Northwest Research Station, Portland, Oregon, USA

Unsworth JW, Kuck L, Garton EO, Butterfield BR (1998) Elk habitat selection on the Clearwater National Forest, Idaho. Journal of Wildlife Management 62:1255-1263

Van Deelen TR, McKinney LB, Joselyn MG, Buhnerkempe JE (1997) Can we restore elk to southern Illinois? The use of existing digital land-cover data to evaluate potential habitat. Wildlife Society Bulletin 25:886-894
Western Regional Climate Center (WRCC) (2007) WRCC: Chadron 1 NW, Nebraska (251575). Accessed online December 9, 2007: http://www.wrcc.dri.edu/cgi-bin/cliMAIN.pl?ne1575

Wichrowski MW, Maehr DS, Larkin JL, Cox JJ, Olsson MPO (2005) Activity and movements of reintroduced elk in southeastern Kentucky. Southeastern Naturalist 4:365-374

Wisdom MJ, Bright LR, Carey CG, Hines WW, Pederson RJ, Smithey DA, Thomas JW, Witmer GW (1986) A model to evaluate elk habitat in western Oregon. R6-F\&WL-216. U.S. Forest Service, Pacific Northwest Research Station, Portland, Oregon, USA

Wisdom MJ, Cimon NJ, Johnson BK, Garton EO, Thomas JW (2004) Spatial partitioning by mule deer and elk in relation to traffic. Transactions of the North American Wildlife and Natural Resources Conference 69:509-530

Witmer GW (1990) Reintroduction of elk in the United States. Journal of the Pennsylvania Academy of Science 64:131-135

Witmer GW, Wisdom MJ, Harshman EP, Anderson RJ, Carey C, Kuttel MP, Luman ID, Rochelle JA, Scharpf RW, Smithey D (1985) Deer and elk. In: Brown ER (ed) Management of wildlife and fish habitats in forests of western Oregon and Washington. R6-f\&WL-192, U.S. Forest Service, U.S. Government. Printing Office, Washington, D.C., USA, pp 231-258 